\title{
Comparative studies on the concentration of rare earth elements and heavy metals in the atmospheric particulate matter in Beijing, China, and in Delft, the Netherlands
}

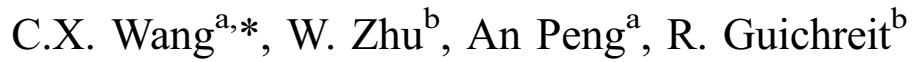 \\ ${ }^{a}$ State Key Laboratory of Environmental Aquatic Chemistry, Research Center for Eco-Environmental Sciences, Chinese Academy of Sciences, \\ P.O. Box 2871, Beijing 100085, People's Republic of China \\ ${ }^{\mathrm{b}}$ Department of Analytical Chemistry, TNO Institute of Environmental Sciences, Energy Research and Process Innovation, \\ P.O. Box 342, Apeldoorn 7300 AH, Netherlands
}

\begin{abstract}
Atmospheric particulate matter (APM) was collected at three sampling sites in Beijing, China, from February to June 1998. The concentrations of rare earth elements (REE) and cobalt $(\mathrm{Co})$, zinc $(\mathrm{Zn})$, copper $(\mathrm{Cu})$, cadmium $(\mathrm{Cd})$ and lead $(\mathrm{Pb})$ in the $\mathrm{APM}$ were determined by inductively coupled plasma mass spectrometry (ICP-MS). The results obtained in Beijing, China, were compared to that obtained in Delft, the Netherlands, in 1997. The influence of coal combustion was considered. The results demonstrated that the content of APM, the concentrations of REE and $\mathrm{Co}, \mathrm{Zn}, \mathrm{Cd}, \mathrm{Pb}$ in the APM in Beijing, China, were higher than that in Delft, the Netherlands. From the ratios of La to Ce, and La to Sm, which may be used as tracers for the origin of the REE, it is concluded that the origins of REE in China differ from those in the Netherlands. (C) 2001 Elsevier Science Ltd. All rights reserved.
\end{abstract}

Keywords: Atmospheric particulate matter; Heavy metals; Rare earth elements

\section{Introduction}

Air pollution in urban areas arises from a multitude of source; anthropogenic activity is a major contributor. The concentrations of carbon monoxide, oxides of nitrogen, sulphur dioxide, ozone, unburnt hydrocarbon and smoke in the atmosphere have been widely determined and studied (Williams, 1987; Harrop et al., 1988; Werner and Meckel, 1989; Lelieveld, 1989; Ueda et al., 1989). This is because of their adverse effects on human health and nature. In the past 10 years, considerable work has been devoted to the concentration distribution of rare earth elements (REE) in soil and natural waters in different areas of China (Peng and Wang, 1995; Zhang et al., 1994; Ni, 1995; Ding, 1995), but little work has been done on the concentration of REE in air. China has the largest rare earth reserves in the world; the industrial reserves occupy first place $(76 \%)$ and China is a major producer of REE for the world market. The

\footnotetext{
* Corresponding author. Tel.: +86-10-6292-3541; fax: +86-10-62923563.

E-mail address: chunxia@mail.rcees.ac.cn (C.X. Wang).
}

application of REE has been rapidly expanded in industry, but also in agriculture, forestry and animal husbandry because of their effects on increasing crop production. The Netherlands, the largest country for REE import, imports about $10 \%$ of rare earths for a variety of purposes. Along with a worldwide increase in use of rare earths, these elements have increasingly been emitted into the atmosphere. Therefore, it is of importance to determine their levels in ambient air.

Distribution of elements and organic pollutants in airborne particulate matter gives a unique opportunity for improving knowledge on air quality and source attribution of atmospheric pollution. In this study, we mainly focused on the determination of atmospheric particulate matter (APM) content and concentrations of REE and five heavy metals, cobalt $(\mathrm{Co})$, zinc $(\mathrm{Zn})$, copper $(\mathrm{Cu})$, cadmium $(\mathrm{Cd})$ and lead $(\mathrm{Pb})$ in APM in Beijing, China, to investigate the air quality on these aspects. The results were compared to those we have determined by the same methods in the Netherlands in 1997 to understand the extent of REE and heavy metal pollution in air in these two contrasting countries. The influence of coal combustion in China on the concentrations of REE and heavy metals was taken into account. 


\section{Materials and methods}

\subsection{Sampling}

APM was collected from February to June 1998 in Beijing, China, on microquartz glass fibre filter paper ( 8 in. $\times 10$ in.; Chemical Sciences, Ann Arbor, MI, USA) using a SIBATA High-Volume Air Sampler (Japan; air flow rate was $1 \mathrm{~m}^{3} / \mathrm{min}$ ). Samples were taken at three sites in Beijing characterized by different environmental conditions, and namely HR, SJ and SQ. Location HR was in Huairou county, a suburb of Beijing, an agricultural area and taken as a lightly polluted area. Location SJ was $100 \mathrm{~m}$ from the Beijing Iron and Steel, which is situated at the Shijingshan District, in the west-south of Beijing City. Shijingshan is the most important energy consumption district and accounts for $40 \%$ of total energy consumption of Beijing (Group of Investigation for Industry Pollution Sources of China, 1991). There are six large-scale heavy industrial enterprises and these represent heavily polluted areas in Beijing. Location SQ was our institute in the north-west district of Beijing and was taken as representing a medium polluted area. The number of samples taken at these three sites was 7 during February to early March (coal combustion period); seven samples were also collected at SQ during May to June (non-coal burning period). Before and after each sampling period, the filters were conditioned under constant relative humidity $(50 \pm 5 \%)$ and temperature $\left(22 \pm 2{ }^{\circ} \mathrm{C}\right)$ for $24 \mathrm{~h}$ and weighed to determine the weight of particulate matter.

\subsection{Extraction and analysis of REE and heavy metals}

The whole filter sample was used for extraction of the REE and other metals. The filter paper was cut into small pieces $\left(1 \times 3 \mathrm{~cm}^{2}\right)$ using plastic scissors and subsequently leached for $4 \mathrm{~h}$ with $45 \mathrm{~cm}^{3} 43 \% \mathrm{HNO}_{3}$ (super pure; Beijing Chemical, China). The leaching solution was filtered and transferred to a volumetric flask and diluted to $100 \mathrm{~cm}^{3}$ with double-distilled de-ionized water.

The concentrations of REE and five heavy metals $(\mathrm{Cu}$, $\mathrm{Co}, \mathrm{Zn}, \mathrm{Pb}$ and $\mathrm{Cd}$ ) were analyzed by inductively coupled

Table 1

ICP-MS operating parameters for aqueous REE and heavy metals analyses

\begin{tabular}{ll}
\hline Forward power $(\mathrm{W})$ & 1350 \\
Reflected power $(\mathrm{W})$ & $<5$ \\
Nebuliser gas flow rate $\left(\mathrm{dm}^{3} / \mathrm{min}\right)$ & 0.8 \\
Auxiliary gas flow rate $\left(\mathrm{dm}^{3} / \mathrm{min}\right)$ & 0.9 \\
Coolant argon flow rate $\left(\mathrm{dm}^{3} / \mathrm{min}\right)$ & 14 \\
Sampling uptake rate $\left(\mathrm{cm}^{3} / \mathrm{min}\right)$ & 1.0 \\
Sampler $($ nickel) orifice $(\mathrm{mm})$ & 1.0 \\
Skimmer (nickel) orifice $(\mathrm{mm})$ & 0.7 \\
Third stage pressure $(\mathrm{mbar})$ & $1.7 \times 10^{-6}$ \\
Mass range $(m / z)$ & $50-180$ \\
Data acquisition & Range-scanning mode \\
Total acquisition time & $60 \mathrm{~s}$ \\
\hline
\end{tabular}

plasma mass spectrometry (ICP-MS; VG Plasma Quad Plus, Fisons Instruments, UK). Operating conditions are shown in Table 1. The ICP-MS was optimised with a solution of 100 $\mathrm{ng} / \mathrm{cm}^{3}$ indium ( ${ }^{115} \mathrm{In}$, Alfa; Johnson Matthey, Germany) in $3 \% \mathrm{HNO}_{3}$. The internal standard used during the analysis of the samples was ${ }^{115} \mathrm{In}$ at $50 \mathrm{ng} / \mathrm{cm}^{3}$ concentration in $3 \%$ $\mathrm{HNO}_{3}$. The following masses for REE and heavy metals by ICP-MS measurement were used: ${ }^{59} \mathrm{Co},{ }^{64} \mathrm{Zn},{ }^{65} \mathrm{Cu},{ }^{89} \mathrm{Y}$, ${ }^{111} \mathrm{Cd},{ }^{139} \mathrm{La},{ }^{140} \mathrm{Ce},{ }^{141} \mathrm{Pr},{ }^{146} \mathrm{Nd},{ }^{147} \mathrm{Sm},{ }^{153} \mathrm{Eu},{ }^{157} \mathrm{Gd}$, ${ }^{159} \mathrm{~Tb},{ }^{163} \mathrm{Dy},{ }^{165} \mathrm{Ho},{ }^{166} \mathrm{Er},{ }^{169} \mathrm{Tm},{ }^{172} \mathrm{Yb},{ }^{175} \mathrm{Lu}$ and ${ }^{208} \mathrm{~Pb}$.

\section{Results and discussion}

Table 2 shows the APM content and the mean, maximum and minimum concentrations of REE and other five heavy metals in the APM collected from February to March during the coal burning period in 1998 in Beijing at the three sampling sites. The results for the samples collected from May to early June at SQ, during the non-coal burning period, are listed as well to illustrate the contribution of coal combustion on the concentrations of REE and heavy metals. In order to compare the APM contents of the concentrations of REE and heavy metals in APM for China and the Netherlands, the results obtained in 1997 in the Netherlands are also tabulated.

As shown in Table 2, APM content had a range of $0.159-2.01 \mathrm{mg} / \mathrm{m}^{3}$ in Beijing at the three sampling sites, and the arithmetic mean was $0.268,1.174$ and $0.496 \mathrm{mg} / \mathrm{m}^{3}$ for HR, SJ and SQ, respectively. Coal is the main energy source of Beijing and accounts for $87 \%$ of the five energy resources: coal, coke, oil, gas and electricity. Coal combustion is thus the main contributor to the air pollution in Beijing. With respect to the results at the SQ site, the APM content in winter time with coal burning ( $\left.\mathrm{SQ}^{\prime}\right)$ was almost twofold that in the summer time, non-coal burning (SQ) period. There were more fly ash particles from coal combustion in winter. Compared to that in Delft, the APM content in atmospheric particles in Beijing was 4.6-21 times higher. It has been clearly indicated that particulate matter severely affects the air quality in Beijing.

It can be observed from Table 2 and Fig. 1 that the order of the concentrations of REE in APM in Beijing was as follows: $\mathrm{Ce}>\mathrm{La}>\mathrm{Nd}>\mathrm{Y}>\mathrm{Pr}>\mathrm{Sm}>\mathrm{Gd}>\mathrm{Dy}>\mathrm{Er}>\mathrm{Yb}>\mathrm{Eu}>\mathrm{Tb}>$ Ho $>\mathrm{Tm}>\mathrm{Lu}$, showing only small fluctuations after Pr for these three sampling sites. The sequence was similar to that in Delft, the Netherlands, determined in 1997 (Wang et al., 2000), and similar to the order of REE in the sediments (Zhu et al., 1997), animal, plant, environmental and geological samples (Wang et al., 1995; Zhong and Min, 1995).

Particles in the atmosphere consist mainly of light REE like $\mathrm{La}, \mathrm{Ce}, \mathrm{Pr}, \mathrm{Nd}, \mathrm{Sm}$ and $\mathrm{Y}$ as well, which was more than $90 \%$ of the total atmospheric REE burden. The concentrations of single REE conformed to the distribution law of odd-even numbers. The notably high Ce values may arise from the use of $\mathrm{Ce}$ in the catalyst in automobiles. 
Table 2

Comparison of concentrations of APM $\left(\mathrm{mg} / \mathrm{m}^{3}\right)$, REE and heavy metals $\left(\mathrm{ng} / \mathrm{m}^{3}\right)$ at three sites in Beijing, China, and in Delft, the Netherlands

\begin{tabular}{|c|c|c|c|c|c|}
\hline Sampling sites & HR & SJ & Delft & SQ & $\mathrm{SQ}^{\prime}$ \\
\hline $\mathrm{APM}\left(\mathrm{mg} / \mathrm{m}^{3}\right)$ & $0.268(0.159-0.383)$ & $1.174(0.527-2.01)$ & $0.056(0.0201-0.160)$ & $0.496(0.217-0.674)$ & $0.257(0.166-0.372)$ \\
\hline Y & $3.28(2.12-4.18)$ & $11.51(4.91-17.73)$ & $0.294(0.0068-2.05)$ & $5.22(2.75-6.75)$ & $1.84(0.95-2.37)$ \\
\hline $\mathrm{La}$ & $5.12(2.97-6.88)$ & $17.03(7.74-26.11)$ & $0.504(0.0415-1.724)$ & $6.934(3.85-8.90)$ & $5.052(2.00-7.13)$ \\
\hline $\mathrm{Ce}$ & $10.43(6.06-13.99)$ & $38.7(16.13-58.63)$ & $0.592(0.0469-3.233)$ & $13.89(7.03-18.05)$ & $9.862(4.00-14.29)$ \\
\hline $\operatorname{Pr}$ & $1.26(0.72-1.68)$ & $4.09(1.81-6.37)$ & $0.109(0.0072-0.408)$ & $1.55(0.85-1.98)$ & $1.517(0.75-2.01)$ \\
\hline $\mathrm{Nd}$ & $4.03(2.36-5.38)$ & $13.50(5.66-21.15)$ & $0.345(0.0178-1.700)$ & $5.42(3.23-6.81)$ & $4.08(1.99-5.58)$ \\
\hline Sm & $0.86(0.49-1.11)$ & $2.82(1.03-4.44)$ & $0.0635(0.0072-0.348)$ & $0.997(0.50-1.29)$ & $0.739(0.31-1.02)$ \\
\hline $\mathrm{Eu}$ & $0.18(.012-0.24)$ & $0.59(0.24-0.86)$ & $0.0182(0.0019-0.0916)$ & $0.223(0.12-0.31)$ & $0.232(0.14-0.35)$ \\
\hline $\mathrm{Gd}$ & $0.83(0.49-1.12)$ & $2.57(1.1-4.18)$ & $0.0698(0.0061-0.336)$ & $0.970(0.55-1.25)$ & $1.214(0.75-1.64)$ \\
\hline $\mathrm{Tb}$ & $0.12(0.06-0.16)$ & $0.33(0.14-0.52)$ & $0.0084(0.0003-0.0436)$ & $0.144(0.08-0.17)$ & $0.181(0.10-0.25)$ \\
\hline Dy & $0.54(0.34-0.71)$ & $1.63(0.72-2.47)$ & $0.0460(0.0027-0.242)$ & $0.770(0.48-0.98)$ & $0.838(0.48-1.18)$ \\
\hline Ho & $0.11(0.07-0.15)$ & $0.29(0.13-0.39)$ & $0.0086(0.0005-0.0444)$ & $0.141(0.09-0.18)$ & $0.081(0.04-0.12)$ \\
\hline $\mathrm{Er}$ & $0.30(0.19-0.35)$ & $0.82(0.40-1.24)$ & $0.0234(0.0010-0.122)$ & $0.400(0.20-0.55)$ & $0.339(0.18-0.48)$ \\
\hline $\mathrm{Tm}$ & $0.04(0.02-0.04)$ & $0.11(0.05-0.18)$ & $0.0030(0.0004-0.0154)$ & $0.053(0.03-0.07)$ & $0.026(0.01-0.04)$ \\
\hline $\mathrm{Yb}$ & $0.22(0.15-0.28)$ & $0.65(0.27-1.04)$ & $0.0235(0.0093-0.0973)$ & $0.309(0.18-0.39)$ & $0.209(0.11-0.31)$ \\
\hline $\mathrm{Lu}$ & $0.04(0.02-0.05)$ & $0.09(0.04-0.13)$ & $0.0027(0.0004-0.0144)$ & $0.047(0.02-0.06)$ & $0.029(0.02-0.05)$ \\
\hline LREE & $25.15(14.85-33.47)$ & $88.15(37.52-135.29)$ & $4.04(0.21-30.68)$ & $34.23(18.34-43.69)$ & $23.33(10.14-32.73)$ \\
\hline HREE & $2.19(1.33-2.88)$ & $6.49(2.86-10.14)$ & $0.31(0.01-2.32)$ & $2.834(1.63-3.64)$ & $2.92(1.70-4.06)$ \\
\hline - REE & $27.34(16.18-36.35)$ & $94.65(40.38-145.43)$ & $4.35(0.22-33.0)$ & $37.07(19.97-47.33)$ & $26.24(11.83-36.69)$ \\
\hline $\mathrm{L} / \mathrm{H}^{\mathrm{a}}$ & $11.47(11.18-11.62)$ & $13.57(13.14-14.09)$ & $11.06(6.37-33.58)$ & $12.08(11.22-12.72)$ & $7.99(5.97-9.23)$ \\
\hline $\mathrm{L} / \cdot \mathrm{REE}^{\mathrm{b}}$ & $0.920(0.918-0.921)$ & $0.93(0.929-0.934)$ & $0.90(0.899-0.912)$ & $0.924(0.918-0.927)$ & $0.889(0.857-0.902)$ \\
\hline $\mathrm{La} / \mathrm{Ce}$ & $0.491(0.489-0.492)$ & $0.441(0.409-0.485)$ & $1.11(0.50-4.38)$ & $0.500(0.483-0.548)$ & $0.512(0.477-0.549)$ \\
\hline $\mathrm{La} / \mathrm{Sm}$ & $5.962(5.664-6.196)$ & $6.04(5.50-7.51)$ & $12.57(4.33-71.12)$ & $6.958(6.779-7.685)$ & $6.838(6.003-7.476)$ \\
\hline $\mathrm{Cd}$ & $0.95(0.54-1.39)$ & $2.43(1.48-2.96)$ & $0.458(0.051-3.255)$ & $4.44(1.19-8.42)$ & $1.67(0.61-3.59)$ \\
\hline $\mathrm{Pb}$ & $81.50(50.29-138.75)$ & $219.84(149.6-255.0)$ & $16.64(3.082-60.69)$ & $404.39(94.36-699.7)$ & $245.07(120.14-361.46)$ \\
\hline Co & $3.75(2.57-4.73)$ & $15.65(6.59-22.53)$ & $0.147(0.033-0.273)$ & $7.09(3.86-9.63)$ & $1.83(0.93-2.29)$ \\
\hline $\mathrm{Cu}$ & $36.48(22.57-60.94)$ & $162.28(127.7-190.9)$ & $138.78(42.19-217.31)$ & $154.46(89.44-332.78)$ & $39.06(22.97-61.94)$ \\
\hline $\mathrm{Zn}$ & $124.57(67.8-203.2)$ & $519.58(288.4-1014)$ & $21.35(6.22-36.65)$ & $453.55(111.7-698.6)$ & $148.61(77.01-262.9)$ \\
\hline
\end{tabular}

a The ratio of light REE (La, Ce, Pr, Nd, Sm, Eu) to heavy REE (Gd, Tb, Dy, Ho, Er, Tm, Yb, Lu, Y).

$\mathrm{b}$ The ratio of light REE to total REE.

The concentration of every REE at these three sampling sites in Beijing was around 10-40 (Ce at SJ was 65) times higher than that in the Netherlands, as found by Yang et al.
(1993). This should be attributed to the rich resources of REE ore and widespread use and production in China. Comparing the concentrations of REE and $\mathrm{Cd}, \mathrm{Pb}, \mathrm{Co}, \mathrm{Cu}$

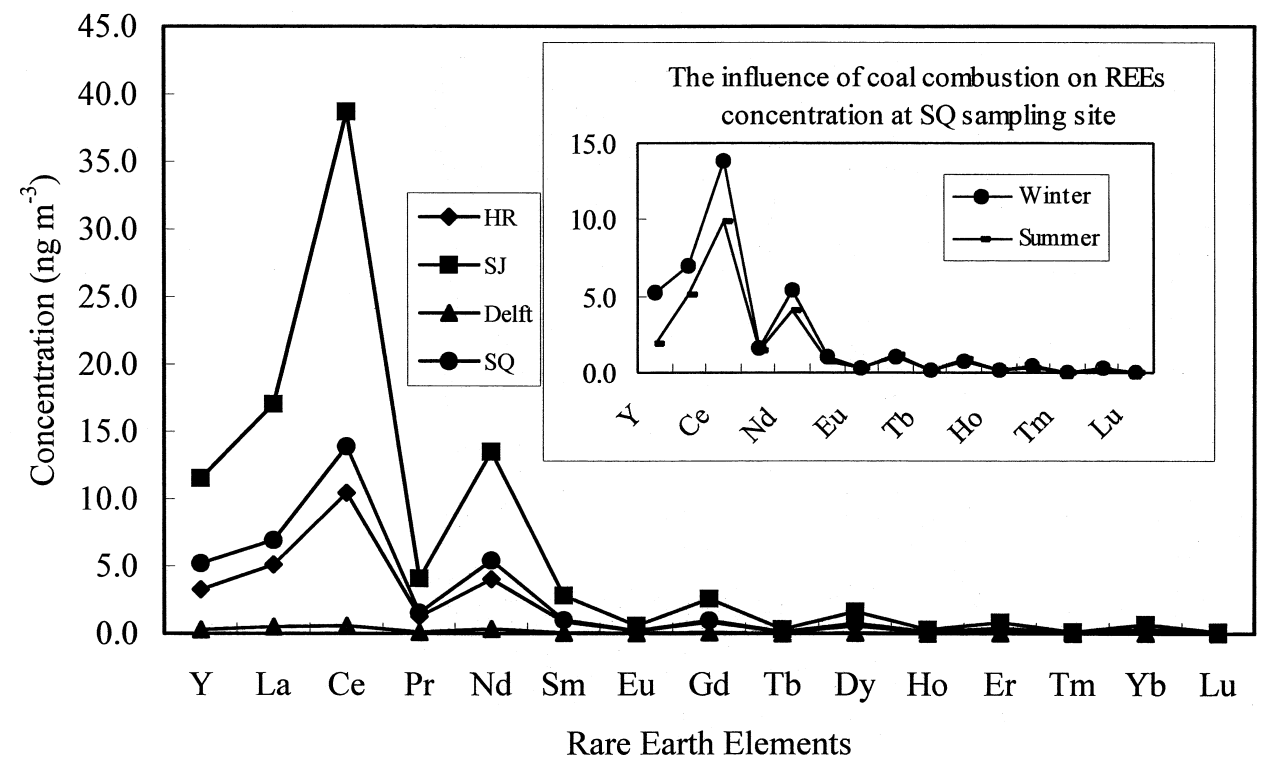

Fig. 1. REE distribution at three sampling sites in Beijing, China, and comparison to that in Delft, the Netherlands (winter: coal combustion period; summer: non-coal combustion period). 
and $\mathrm{Zn}$ at SQ for two seasons (see Figs. 1 and 2), the contribution of coal combustion to the concentrations of REE and especially heavy metals can clearly be seen.

Contents of heavy metals in APM at the three sampling sites in winter time with coal combustion decreased in the order $\mathrm{Zn}>\mathrm{Pb}>\mathrm{Cu}>\mathrm{Co}>\mathrm{Cd}$; but in summer time without coal combustion, the content of $\mathrm{Pb}$ was higher than $\mathrm{Zn}$. The order in the Netherlands was: $\mathrm{Cu}>\mathrm{Zn}>\mathrm{Pb}>\mathrm{Cd}>\mathrm{Co} . \mathrm{Pb}$ and $\mathrm{Zn}$ are known to be emitted mainly from anthropogenic sources such as automobile exhausts, other oil combustion, etc.; they had higher concentrations than other metals. In the Netherlands, the concentration of $\mathrm{Cu}$ in APM was higher than that of $\mathrm{Pb}$ and $\mathrm{Zn}$; this might be due to some kind of copper industry near the sampling site. In general, $\mathrm{Cu}$ and Co were mainly emitted from the industrial area, and thus the concentrations of $\mathrm{Cu}$ and $\mathrm{Co}$ in HR, a residential and agricultural area, were relatively low.

For the three sampling sites in Beijing, the APM contents, concentrations of REE and metals $\mathrm{Zn}, \mathrm{Cu}$ and $\mathrm{Co}$ are higher in SJ than in SQ and HR, and follow the order: $\mathrm{SJ}>\mathrm{SQ}>\mathrm{HR}$. This can be attributed to both high particulate matter resuspension and much heavy industry in the Shi-

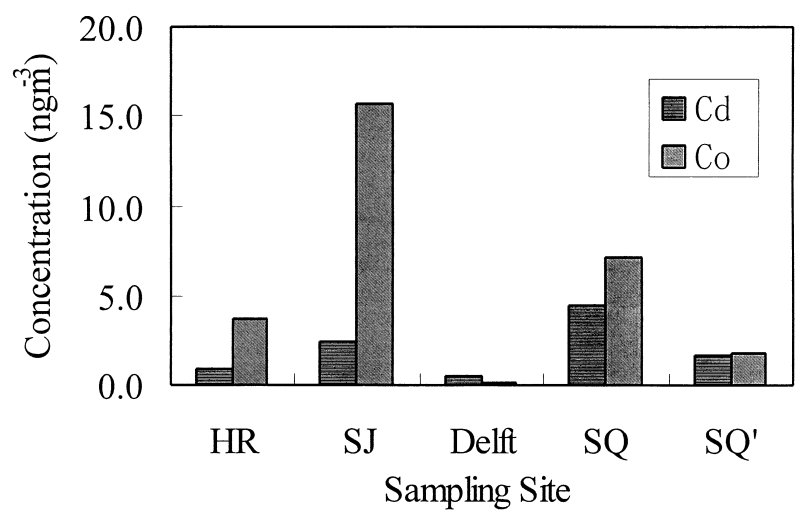

(a)

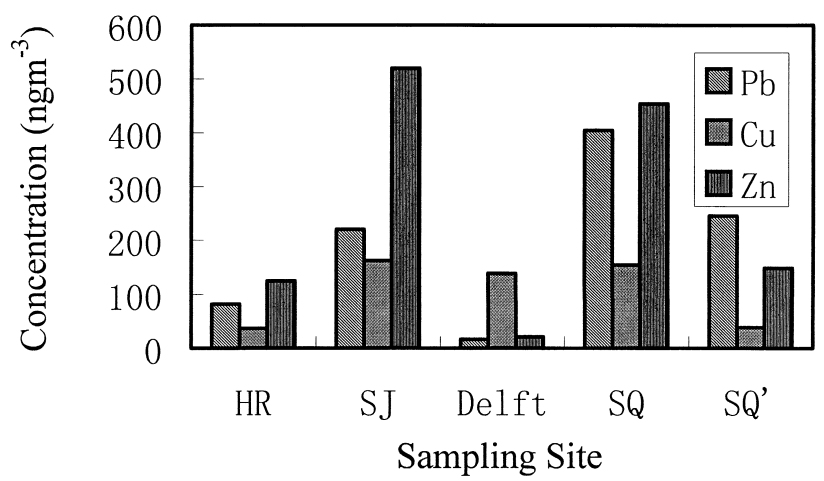

(b)

Fig. 2. Comparison of heavy metals concentration at different sites in Beijing, China, and in Delft, the Netherlands, and the influence of coal combustion: (a) $\mathrm{Cd}$ and $\mathrm{Co}$; (b) $\mathrm{Pb}, \mathrm{Cu}$ and $\mathrm{Zn}$. jingshan district. The concentrations of $\mathrm{Cd}$ and $\mathrm{Pb}$ in $\mathrm{APM}$ at the SQ site were higher than at SJ. This is probably because of more automobiles near site SQ. Most airborne $\mathrm{Pb}$ in urban areas originate from combustion of leaded gasoline (Olmez and Gordon, 1985). Our results show that the origin for $\mathrm{Pb}$ and $\mathrm{Cd}$ was also mainly industry and traffic.

The great variation in ranges of every element from the minimum and maximum values in Table 2 indicates that the concentration of REE, light REE (LREE), heavy REE (HREE), total REE ( $\sum$ REE) and other five metals in the APM are obviously different from day to day. The levels of these elements strongly depend upon the environmental and geochemical features of each sampling site. Furthermore, the levels of REE and heavy metals are generally higher in winter than in the summer season, especially in the coalconsuming country.

A high $\mathrm{La} / \mathrm{Sm}$ is the one of the most reliable indicators of refinery emissions (Kitto et al., 1992). Loss of REE zeolites into refined oils may have been responsible for the high La/Sm (27 \pm 7$)$ measured in the stack of an oil-fired power plant. Olmez and Gordon (1985) demonstrated that the REE ratios (La to other REE) in emissions from petroleum-refining and oil-burning sources could be used to distinguish them from other sources. For atmospheric emissions from a refinery and a coal- and an oil-fired power plant, La/Sm reported (Olmez and Gordon, 1985) were 20, 5.2 and 28 , respectively. The $\mathrm{La} / \mathrm{Ce}$ was $0.491,0.441$, $0.500,0.512$ and the $\mathrm{La} / \mathrm{Sm}$ was $5.96,6.04,6.96$ and 6.84, for HR, SJ, SQ and $\mathrm{SQ}^{\prime}$, respectively, in our study as shown in Table 2. The ratios of $\mathrm{La}$ to $\mathrm{Ce}$ and $\mathrm{La}$ to $\mathrm{Sm}$ in APM collected at the three sampling sites in Beijing changed very slightly and were relatively stable from day to day. The ratios of $\mathrm{La} / \mathrm{Ce}$ and $\mathrm{La} / \mathrm{Sm}$ in APM were close to those of the crustal ratios of 0.5 and 4.8 , respectively (Kitto et al., 1992), suggesting that the origin of REE in APM in Beijing was similar at these three sampling sites, namely, local soil and coal fly ash. The ratios of $\mathrm{La} / \mathrm{Ce}$ and $\mathrm{La} / \mathrm{Sm}$ in Delft were $1.11(0.50-4.38)$ and $12.57(4.33-$ 71.12), respectively (see Table 2), and showed great variations and strict dependence upon the wind direction (Wang et al., 2000). These ratios were much higher than that of the crustal ratios and that in Beijing, which indicate some REE use and emissions from an oil-fired power plant as well in the Netherlands.

\section{Conclusion}

We suggest that with the increasing use of a wide variety of REE and metals in industry and in our daily life, REE and heavy metals could be dispersed into the biosphere through industrial effluents, organic wastes, refuse burning, transport and power generation. The pollution of air was variable and closely related to human activity. The air quality in Beijing is worse than that in the Netherlands. The origin of REE and heavy metals in these two countries is different. In Beijing, 
REE and heavy metals mostly come from local soils and coal fly ash, and in the Netherlands, they are mostly from industry and traffic.

\section{Acknowledgments}

This work was supported by grants (29890280-1) from the National Natural Science Foundation of China and Research Center for Eco-Environmental Sciences (RCEESKIP-9901). The authors also thank Dr. Junhua Liu and Mrs. Wenhua Wang of the Research Center for EcoEnvironmental Sciences, Chinese Academy of Sciences, for their help in sample collection, and Mrs. Shuzhen Zhang from the same institute for her help with the ICPMS measurements.

\section{References}

Ding WX. Rare earth elements in Chinese soils. J Rare Earth Elem 1995; 15:44-8 (in Chinese).

Group of Investigation for Industry Pollution Sources of China. Evaluation and research on the investigation of industry pollution sources in China. Chinese Environmental Sciences Publisher, Beijing 1991. pp. 1-17 (in Chinese).

Harrop DO, Ashworth J, Pepper B, Pritchard S. The impact of motor vehicle emissions on urban air quality. In: Orio AA, editor. Environmental contamination. Edinburgh: CEP Consultants, 1988. pp. 460-2.

Kitto ME, Anderson DL, Gordon GE, Olmen I. Rare earth distributions in catalysts and airborne particles. Environ Sci Technol 1992;26:1368-75.

Lelieveld J. Transboundary air pollution: several years of measurement. In: Brasser LJ, Mulder WC, editors. Man and his ecosystem - Proceedings of the 8th World Clean Air Congress, the Hague, the Netherlands. 1989. pp. 37-42.

Ni JZ. Distribution of rare earth elements in animals, plants and environ- mental samples. In: Ni JZ, editor. Bioinorganic chemistry of rare earth elements. Beijing: Chinese Sci. Publisher, 1995. p. 72 (in Chinese).

Olmez L, Gordon GE. Reports: rare earths: atmospheric signatures for oilfired power plants and refineries. Science 1985;229:966-8.

Peng A, Wang ZJ. Recent research progress on environmental chemistry of rare earth element. Adv Environ Sci 1995;3:22-32 (in Chinese).

Ueda H, Kuroda T, Kitada T, Carmichael GR. Nitrogen dioxide pollution in the winter urban area band emission-reduction strategy against it. Numerical experiment. In: Brasser LJ, Mulder WC, editors. Man and his ecosystem - Proceedings of the 8th World Clean Air Congress, the Hague, the Netherlands. 1989. pp. 395-400.

Wang HY, Wang DX, Wang YH, Chen SG, Zhang FJ. Application of pattern recognition in a factor analysis - spectrophotometric method for the simultaneous determination of rare earth elements in geological sample. Analyst 1995;5:1603-8.

Wang CX, Zhu W, Wang ZJ, Guicherit R. Rare earth elements and other metals in atmospheric particulate matter in the western part of the Netherlands. Water, Air, Soil Pollut 2000;121(1-4):109-18.

Werner H, Meckel U. Ambient air monitoring in the GDR and quality assurance measures taken by the state sanitary inspectorate. In: Brasser LJ, Mulder WC, editors. Man and his ecosystem - Proceedings of the 8th World Clean Air Congress, the Hague, the Netherlands. 1989. pp. $1-6$.

Williams ML. The impact of motor vehicles on air pollutant emissions and air quality in the UK — an overview. Sci Total Environ 1987;59:47-61.

Yang SJ, Yang YN, Chen BR. The sources and the characteristics of aerosol in the air of West Pacific area. Acta Sci Circumstantiae 1993;13(2): $135-42$ (in Chinese).

Zhang S, Wang LJ, Zhang CS. Neutron activation technique and geobiochemical behavior of rare earth elements. Modern nuclear analysis and its application in environment. Beijing: Publisher for Nuclear Energy, 1994. p. 199 (in Chinese).

Zhong S, Min W. Distribution of rare earth elements in animals, plants and environmental samples. In: $\mathrm{Ni} \mathrm{G}$, editor. Bioinorganic chemistry of rare earth elements. Beijing: Science Press, 1995. pp. 59-114 (in Chinese).

Zhu W, Kennedy M, de Leer EWB, Zhou H, Alaerts GJFR. Distribution and modelling of rare earth elements in Chinese river sediments. Science Total Environ 1997;204:133-43. 